ZOOLOGIA 28 (4): 488-494, August, 2011

doi: $10.1590 /$ S1984-46702011000400010

\title{
Vascularization of the small intestine in lesser anteaters, Tamandua tetradactyla (Xenarthra: Myrmecophagidae)
}

\author{
Jussara R. Ferreira1,3; Ana Lúcia R. Souza²; Amanda R. Mortoza' \& Lorenna C. Rezende ${ }^{1}$
}

\author{
${ }^{1}$ Laboratório de Macro e Mesoscopia, Faculdade de Medicina, Universidade de Brasília. Campus Darcy Ribeiro, Asa Norte, \\ 70910-900 Brasília, DF, Brazil. \\ ${ }^{2}$ Laboratório de Anatomia, Universidade Federal de Goiás. Setor Parque Industrial, 75801-615 Jataí, GO, Brazil. \\ ${ }^{3}$ Corresponding author. E-mail: jussararocha@unb.br
}

\begin{abstract}
The blood supply in the small intestine of seven Tamandua tetradactyla (Linnaeus, 1758), was studied. The method included preparation of the macroscopic collection report, perfusion of the arterial network with water $\left(40^{\circ} \mathrm{C}\right)$, injection of colored latex (Neoprene $650^{\circledR}, 2350-0003$ Suvinil ${ }^{\circledR}$ dye), fixation in formaldehyde (10\%), and preservation in ethanol (50\%). For description and analyzes, dissection under mesoscopic light and photo documentation were performed. The small intestine of $T$. tetradactyla is irrigated by the cranial mesenteric artery, the ventral visceral branch of the abdominal aorta. The artery emerges from the retroperitoneum and disperses between the layers of the common mesentery, parallel to the caudal mesenteric artery. The primary cranial collateral branches irrigate the pancreas, duodenum, jejunum (13 arteries), ileum (14 vessels), and the cecocolic region. The arteries anastomose with adjacent vessels to form arches. Terminal branches are derived from these peri-intestinal arcs that reach into the intestine through the mesenteric boundary and form capillaries within the lining. The vascular pattern of the lesser anteater differs from those of other previously described vertebrates, but is similar to the pattern found in fetuses of domestic mammals during early intestinal development.
\end{abstract}

KEY WORDS. Artery; digestive system; mesoscopy.

Due to their functional requirements, complex organisms have developed extremely sophisticated circulatory systems. This is evident, for instance, in the digestive tract, where the vascular network has co-evolved with organs of the digestive system: the rumen, the stomach, the coelom, and the mesentery. Each of those organs has unique adaptations in their mucous membranes.

The unique eating habits and body design of the members of the Xenarthra, present in Central and South America (GARDNER 2007, GAUdin \& McDonald 2008), have instigated us to investigate how the vessels are distributed in the intestines of Tamandua tetradactyla (Linnaeus, 1758). Since there is no available description of these vessels for other Tamandua species, we compared the patterns observed in T. tetradactyla with those of other species of Xenarthra and other suborders.

In the evolution of the digestive tract of herbivores, carnivores, and omnivores, the various organs have become adapted to meet their specific digestive needs. Adaptations in the coelom and mesentery, including their blood supply, were necessary to ensure the proper digestion and storage of food, and the expulsion of feces (Hildebrand \& Goslow 2006). In order to ensure a sufficient supply of oxygen and glucose to the intestines, the arteries arising from the celiac trunk and mesentery branch nourish the anterior and middle intestine (BRUNI \& Zimmerl 1947, Llorca 1952, Testut \& Latarjet 1960, Grassé 1965, SCHWARZE \& SCHröDER 1970, Nickel \& SChummer 1977, MoOre \& Persaud 2008, Lima et al. 2010), whereas the caudal mesentery nourishes the distal bowel. These vessels have been previously described in human and non-human primates (RAVEN 1950, Zappalá 1963, Moore \& Persaud 2008), rodents (Carvalho et al. 1999, Machado et al. 2006, Culau et al. 2008), birds (Pinto et al. 1998), turtles (Rodrigues et al. 2003), and in several species of ungulates (Peduti Neto \& Prada 1970, Pereira et al. 1978, Barnwal et al. 1982, Machado et al. 2000).

Some morphological studies on Xenarthra species have addressed various systems, for instance the digestive (Diz et al. 2006) and reproductive (Grassé 1965) systems. Grassé (1965) described the vascularization of the digestive tract of species of this taxon in general terms, without elaborating on the origin, route, destination, or prominent areas of the arteries that provide vascularization to the small intestine. In the present study, the vascularization of the small intestine in T. tetradactyla, commonly known in the Cerrado region of Brazil as the lesser or collared anteater, is described. 


\section{MATERIAL AND METHODS}

This study is both descriptive and interpretative. Seven adult lesser anteaters, killed on roads in the Brazilian states of Goiás and Paraná (4 males and 3 females), were used. The animals were transported to the Laboratory of Macro and Mesoscopic Research, Faculdade de Medicina, Universidade de Brasília, and to the Museu Dinâmico Interdisciplinar, Universidade Estadual de Maringá. The material was collected and transported under a license from IBAMA (Protocol 18256, November 4,2008$)$. In the laboratory, we cannulated the abdominal aorta of each specimen in order to perfuse warm water $\left(40^{\circ} \mathrm{C}\right)$ into the arterial network, where we injected colored latex (Neoprene $650^{\circledR}$ and Sulvinil Dye 2350-0003 ${ }^{\circledR}$ ). After that, the corpses were fixed in formaldehyde solution (10\%) and preserved in alcohol solution (50\%). Dissections for the characterization of the vessels were performed under mesoscopic light (Lts-Mod. $3700^{\circledR}$ ) and photo-documentation was performed with a digital camera (Nikon $\mathrm{D} 40^{\circledR}$ ). Data analysis included determination of the origin of the arteries, the path of the vessels through the peritoneum (the mesentery and mesocolon), the mode of termination and the presence or absence of anastomoses between the cranial mesenteric artery (CrMA) and the caudal mesenteric artery (CaMA), and the building up of arterial islands between the vascular beds. Anatomical terms used in this contribution are based on the criteria of the Nomina Anatomica Veterinaria (2005). Measurements, unless otherwise specified, are averaged across the samples.

\section{RESULTS}

In the paragraphs below we describe the origin of the cranial mesenteric artery (CrMA), its primary, secondary and arched collateral branches, irrigation zone, and mode of termination. After the general description, we make a note on the exceptions to the patterns we observed.
The CrMA is a intraperitoneal vessel $17.21 \mathrm{~cm}$ long, that crosses the mesentery horizontally with respect to where it emerges from the ventral surface of the abdominal aorta (Tab. I). Other arteries that contribute to the nourishment of the portion of the small intestine irrigated by the CrMA, and a portion of the large intestine, including the caudal mesenteric artery (CaMA), celiac trunk and pancreatic duodenal arteries, are also identified (Fig. 1). The CrMA emerges from the retroperitoneum and enters the abdominal cavity through the mesothelium, the space between the two peritoneal layers, which extends to surround the intestines as the parietal peritoneum.

The parietal peritoneum determines the spatial positioning of the viscera and maintains their anatomic position, besides allowing the passage of blood vessels and nerves.

It is important to note that the peritoneum which upholds fixed the small intestine does not shift from the midline of the body. It is continuous with the mesocolon. In other words, a common mesentery (the cranial mesentery and caudal mesocolon) attached to the dorsal wall by a membrane, extends to the caudal portion of the large intestine and to the cranial portion of the small intestine (Fig. 1).

We found that the CrMA is a ventral visceral branch of the abdominal aorta, caudal to the origin of the celiac trunk. In its path, from the root of the mesentery to the mesenteric edge of the bowel, the CrMA sends dorsal-lateral branches to the duodenum, ventral branches toward the jejunum and ileum, ventral-lateral branches to the cecumand occasionally to the right colic flexure. Exceptions from the description given above are as follows. In one female we found two CrMAs originating from the aorta, following parallel paths for $4 \mathrm{~cm}$ inside the mesentery, then anastomosing and continuing as one vessel (Tab. II). In one male, the origin of the CrMA was found under the muscular part of the left pillar of the diaphragm (therefore outside the abdominal cavity). In two instances, the CrMA was observed sending out suprarenal arteries, one to the left and the other to the right.

\begin{tabular}{|c|c|c|c|c|c|c|}
\hline \multirow{2}{*}{ Specimen } & \multicolumn{6}{|c|}{ Length $(\mathrm{cm})$} \\
\hline & Cranial mesenteric artery & Mesentery & Duodenum (d) & Jejunum (j) & Ileum (i) & Total $(d+j+i)$ \\
\hline Female 1 & 19.00 & 21.50 & 11.00 & 278.00 & 221.00 & 510.0 \\
\hline Female 2 & 15.50 & 22.00 & 13.00 & 227.00 & 220.00 & 460.0 \\
\hline Male 3 & 18.00 & 21.50 & 9.00 & 153.00 & 198.00 & 360.0 \\
\hline Female 4 & 17.00 & 19.50 & 14.50 & 134.00 & 171.00 & 319.5 \\
\hline Male 5 & 17.50 & 19.00 & 13.00 & 166.00 & 199.00 & 378.0 \\
\hline Male 6 & 15.50 & 18.50 & 14.00 & 182.00 & 272.00 & 468.0 \\
\hline Male 7 & 18.00 & 21.00 & 15.00 & 200.00 & 233.00 & 448.0 \\
\hline Mean & 17.21 & 20.42 & 12.78 & 191.42 & 216.28 & 420.5 \\
\hline
\end{tabular}



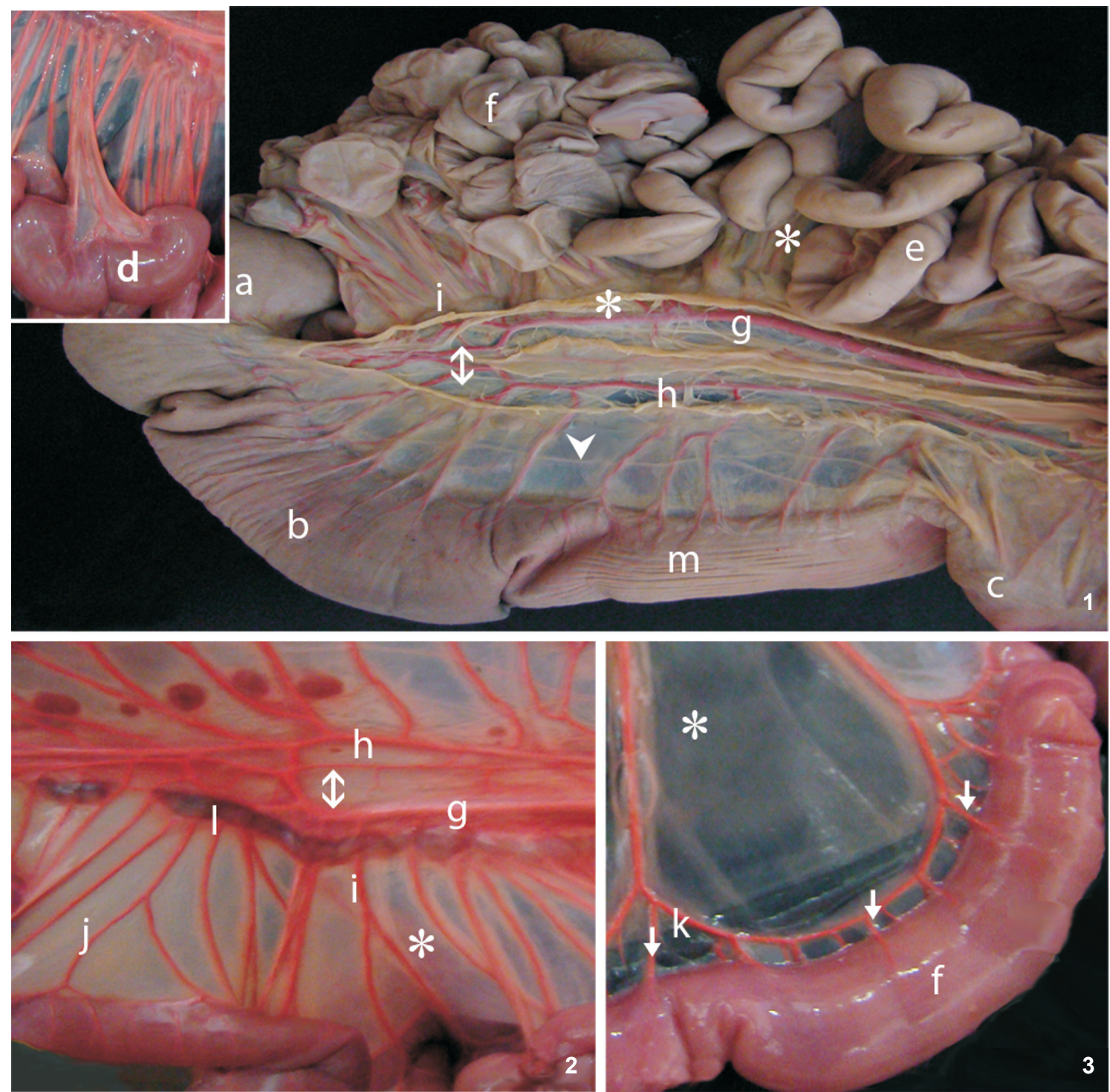

Figures 1-3. Photographs of the digestive tract of T.tetradactyla, overview (1), highlighting vascularization details of the small intestine (2), and some topographic relationships of the arcuate artery with ileal loops (3). (a) Cecum intestine, (b) transverse colon, (c) rectum, (d) detail of the ileal mesentery expansion sustained by the arteries, (e) jejunum, (f) ileum, (g) cranial mesenteric artery, (h) caudal mesenteric artery, (i) primary ileal branch, (j) secondary ileal branch, (k) arcuate artery, (l) juxta-arterial mesenteric lynphonodular grouping, $(\mathrm{m})$ rectum colon, $(\mathfrak{\downarrow})$ inter anastomoses, $(*)$ mesentery, $(\vee)$ mesocolon, $(\downarrow)$ juxta-ileal terminal arteries.

The small intestine is highly vascularized, with a 12.78 cm-long duodenum and a $17.21 \mathrm{~cm}$ long CrMA (Tab. II). This segment is infiltrated by one or two vessels, as follows: two collateral branches of the CrMA irrigate the pancreas, and the duodenum concurrently (two cases); one duodenal artery, emerging from the aorta, goes to the pancreas, anastomosing with another collateral branch of the CrMA; from this point on the joined arteries follow to the duodenum (two cases); one pancreatic duodenal artery (a branch of the celiac trunk) joins with another duodenal artery (a branch of the CrMA) to nourish the duodenum (one case); in two instances, the duodenal artery was identified as corresponding the first collateral branch of the CrMA, also irrigating the pancreas.

On average, 13.14 primary collateral vessels were identified in the jejunum, compared to the 14.42 in the ileum (Tabs I and II). The arched duodenal, jejunal and ileal arteries, where 
they originate, are dependent on the conventional primary or secondary collateral branches. Subsequently they anastamose to form an arch (Figs 4 and 5). These arches eventually become subdivided into first, second and third levels. From the distal arched arteries near the mesenteric border of the intestine, straight terminal branches were observed; as they approach the tube, both dorsally and ventrally, they bifurcate and infiltrate the muscle wall, with their visceral branches directed to the antimesenteric border of the irrigated loop (Fig. 3).

The ileal arteries are also collateral branches of the CrMA; in their origin they are straight, but curve in the first and second levels. This arrangement differs from the ileocecal transition region pattern. In that region, the collateral arteries appear straight regardless of size hierarchy. They branch out from the CrMA trunk and form a dense vascular network near the mesenteric border of the ileum, cecum, and colon (Figs 1 and 3).

The arches formed from the primary ileal arteries appear wider than those of the jejunum (Figs 3 and 5). A significant linear lymphonodular grouping was found along the path of the CrMA.

Multiple variations in the irrigation of the cecum and the initial portion of the colon were found near the transition between the small and large intestines, as follows: in two specimens $(1 \mathrm{~F}, 5 \mathrm{M})$, the CrMA was observed irrigating the entire cecum; in three specimens $(2 \mathrm{~F}, 4 \mathrm{~F}$, and $7 \mathrm{M})$, only $50 \%$ of the cecum was nourished by the CrMA, and the other half by the CaMA; in two specimens ( $3 \mathrm{M}$ and $6 \mathrm{M}$ ), the CrMA was not found to contribute to the nourishment of the cecum; and in one case $(5 \mathrm{M})$, the secondary and tertiary arterial branches of the CrMA were distributed throughout the beginning portion of the colon, in addition to the cecum (Tab. II).

A clear demarcation between the cecum and colon was not found in T. tetradactyla. As expected, a thickening of the muscles and a constriction of the bowel were found at the ileal junction with the large intestine, forming a restricted passage

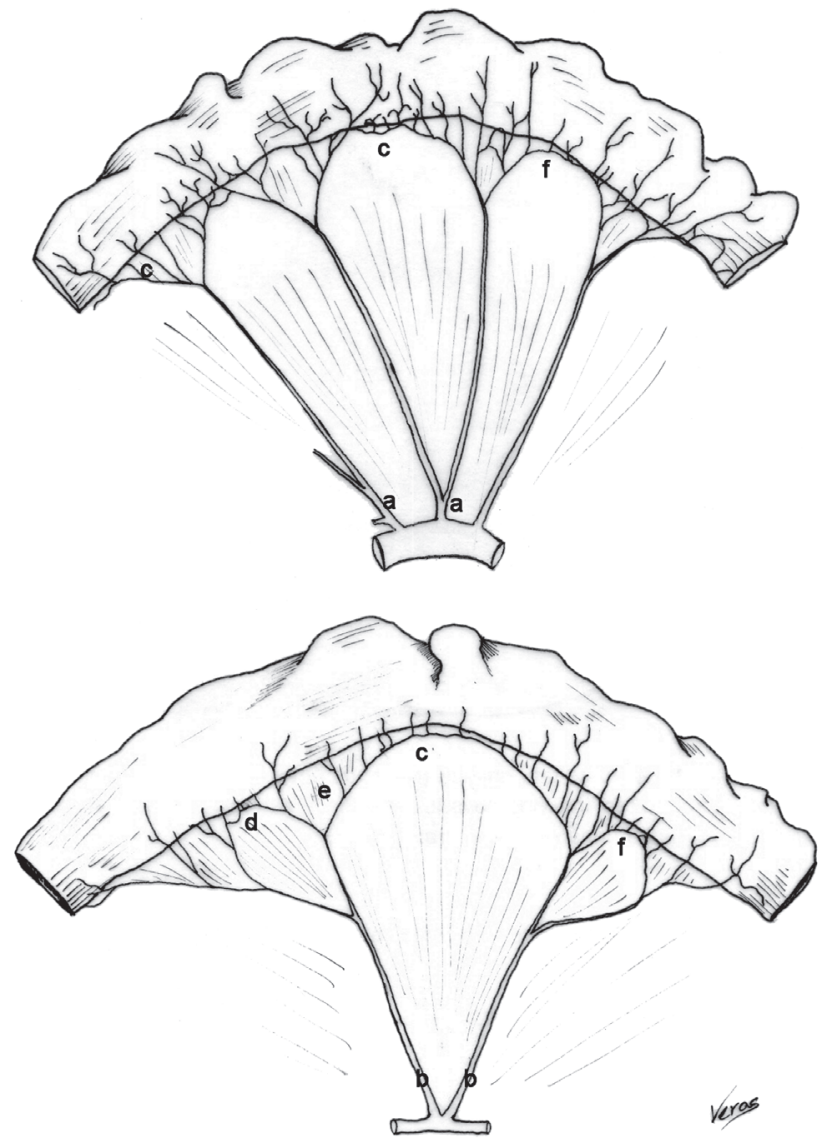

Figures 4-5. Schematic representation of the arcuate jejunal (4) and ileal (5) arteries including: (CrMA) cranial mesenteric artery, (a) primary collateral branches, (b) secondary branches, (c) first-order arcuate artery, (d) second-order arcuate artery, (e) straight terminal arteries, (f) dorsal and ventral branches of the straight arteries.

Table II. Quantitative data of collateral by intestinal sequences dependent on the cranial mesenteric artery and other variable branches of T. tetradactyla, according to specimen and sex. (T. celiac) Celiac trunk artery.

\begin{tabular}{|c|c|c|c|c|c|c|c|c|c|}
\hline \multirow{3}{*}{ Specimen } & \multicolumn{7}{|c|}{ Primary collateral branches } & \multirow{2}{*}{\multicolumn{2}{|c|}{$\begin{array}{c}\text { Variable branches } \\
\text { Pancreatic-duodenal }\end{array}$}} \\
\hline & \multicolumn{7}{|c|}{ Cranial mesenteric artery } & & \\
\hline & Origin & Supra-renal & Pancreatic-duodenal & Jejunum & Ileum & Cecum & Colic & Origin & Quantity \\
\hline Female 1 & Double, aorta & - & 1 & 13 & 14 & 2 & - & T. celiac & 1 \\
\hline Female 2 & Single, aorta & - & 1 & 14 & 14 & 1 & - & Aorta & 1 \\
\hline Male 3 & Single, aorta & - & 1 & 13 & 8 & - & - & - & - \\
\hline Female 4 & Single, aorta & - & 1 & 14 & 13 & 2 & - & Aorta & 1 \\
\hline Male 5 & Single, aorta & 1 & 2 & 15 & 18 & 2 & 2 & - & - \\
\hline Male 6 & Single, aorta & 1 & 3 & 13 & 20 & - & - & - & - \\
\hline Male 7 & Single, aorta & 1 & 2 & 10 & 14 & 1 & 1 & - & - \\
\hline Mean & - & 0.42 & 1.28 & 13.14 & 14.42 & 1.14 & 0.85 & - & 0.42 \\
\hline Total & - & 3 & 9 & 92 & 101 & 8 & 3 & - & 3 \\
\hline
\end{tabular}


lacking ileal papillae. It was also found in the portion of the large intestine that corresponds to the cecocolic junction. At this transition, a sac of approximately $4 \mathrm{~cm}$ in length was found (measured between the probable sphincters in the middle of the intestine). In this region the nourishing vessels, CrMA and CaMA, anastamose either directly or indirectly. The primary, secondary, and tertiary collateral branches along the mesenteric or mesocolic boundary of the ileocecal loops (Figs 1 and 2) decrease in size along their path.

\section{DISCUSSION}

Due to our small sample size, our results cannot be generalized. A broader study on a larger sample would require the sacrifice of animals, which would be neither possible nor sensible, because the species under study is on the endangered species list. In cases like this, small-scale studies are generally acknowledged.

We made interpretations on the network that supplies blood for the three segments of the small intestine. The duodenum, jejunum, and ileum are responsible for metabolic processes and intestinal absorption, thus requiring a large vascular network.

It has been proposed in the literature that the small and large intestines of the adult correspond to the middle and distal intestines of the embryo (Grassé 1965, Noden \& LahunTa 1985, Lat Shaw 1987, Moore \& Persaud 2008). Authors such as Schwarze $\&$ SCHRÖDER (1970) saw the convoluted middle and distal tubes of the embryo and interpreted them as corresponding to the true intestine. The small intestine in the adult is equivalent to the fetal middle intestine. This middle intestine and the vessels which irrigate it keep their connection with the visceral serosa in the adult.

In our samples, the peritoneum consisted of a double layered, U-shaped membrane, with the CaMA and CrMA running through the intermediate space. Although this topography is present during the embryonic stages of life in several species (Llorca 1952, Testut \& Latarjet 1960, Grassé 1965, Junqueira \& Zago 1977, Nickel \& Schummer 1977, Noden \& Lahunta 1985, Lat Shaw 1987, Moore \& Persaud 2008), it has been also observed in adult mammals for instance the anteater M. tridactyla (Souza et al. 2010).

The peritoneal serosa averaged $20.42 \mathrm{~cm}$ in length for the mesentery and mesocolon, or common mesentery referred to by Grassé (1965), whereas the length of the entire small intestine was $428.5 \mathrm{~cm}$. However, there were variations in the number of arteries between the intestinal segments along the bowel.

The total length of the intestine varies between animal species (Schwarze \& Schröder 1970, Nickel \& Schummer 1977, Diz et al. 2006, Pérez et al. 2008) and the length is inversely proportional to the width of the tube. According to previous studies, the composition and quantity of food influence the morphology of the intestine. Reports have correlated the width of the intestinal tube with the weight or width of the body (Clauss et al. 2005, Diz et al. 2006, Pérez et al. 2008) without linking such findings to the blood supply patterns. According to the literature (BRUNi \& ZimmerL 1947, NicKel \& SCHUMmer 1977, GeтTY 1982) the volume that can accumulate in the intestine is proportional to its length. In horses, for example, SchwARze \& SCHRÖDER (1970) described a small intestine of 19-30 m, with a total accumulation capacity of 100 to 150 liters. Although SCHWARZE \& SCHRÖDER (1970) reported the relationship between the length of the intestine and other body segments, they were not able to compare their data with the anteaters analyzed, whose intestinal layout is unique within the superorder Xenarthra (Grassé 1965). SouzA et al. (2010) measured the length of the segments of the large intestine in the giant anteater and studied the blood supply in the species. His study included the topography of the vessels that nourish the digestive tract, which was compared with other vertebrates, confirming that the arteries in Xenarthra exhibit distinct layouts.

Diz et al. (2006) reported a $242 \mathrm{~cm}$-long small intestine in Chaetophractus villosus (Desmarest, 1804). The large intestine of the giant anteater described by Stevens \& Hume (1995) was seven times longer than the length of the body of the specimen. In this study, the anatomy of the small intestine of $T$. tetradactyla was found to be consistent with the aforementioned study. However, Stevens \& Hume (1995) did not describe the topography of the intestinal vessels. This topography has diverged from the vascular layout of the small intestine in domestic mammals (Bruni \& Zimmerl 1947, SchwarZe \& SChröder 1970, GetTy 1982), in human and non-human primates (LloRCA 1952, Didio et al. 1998, Moore \& Persaud 2008), and in carnivores (Lima et al. 2010). In recent vertebrates, there is a major CrMA irrigating from the duodenum to the right colic flexure in the large intestine.

In all specimens analyzed, the CrMA is derived from the aorta. The lack of an attachment between the intestines and the abdominal wall has resulted in a distinct CrMA topography which contrasts with that of other mammals.

The small intestine in the lesser anteater is supplied by the CrMA, which also contributes to the suprarenal glands, the pancreas, cecum, and the rectum. One female in our samples diverged from this general pattern, by having two parallel CrMAs emerging from the aorta. In this individual, the vessels anastamose after $4 \mathrm{~cm}$ into one trunk in the mesothelial peritoneum. The retroperitoneal origin of the CrMA has been confirmed in turtles (Rodrigues et al. 2003), rodents (Carvalho et al. 1999, Machado et al. 2006, Culau et al. 2008), and ungulates (Peduti Neto \& Prada 1970, Machado et al. 2000), and is consistent with our observations.

PINTo et al. (1998) described the CrMA in domestic ducks, showing that the caudal visceral branch of the abdominal aorta also provides a small contribution to the nutrition of the colon. Tamandua tetradactyla exhibits an unusual design of the 
collateral branches; we found that the primary collateral branches of the duodenum and jejunum are perpendicular to the originating vessel, the CrMA. In order to irrigate the small loops, the CrMA sends branches out in the same direction. We did not find any data in the literature to make a comparison. However, it is worth noting that the formation of juxtaintestinal arterial arches, whether duodenal, jejunal or ileal, represents a spatial layout which is partially reproduced in other vertebrates, as demonstrated for horses (Nickel \& Schummer 1977, GetTy 1982), domestic ruminants (Bruni \& Zimmerl 1947, SchwarZe \& Schröder 1970), carnivores (Evans 1993), rodents (Culau et al. 2008), and primates (Didio et al. 1998, Moore \& Dalley 2007).

Consistent with other reports, we have found that the duodenal arteries travel to the most stable part of the intestine, while the jejunal and ileal arteries run in the direction of the mobile part of the small intestinal mesentery. In order to differentiate the jejunal and ileal vessels, we used the criteria established by Didio et al. (1998). The first jejunal loops and the last ileal loops exhibit a relatively different topography because the first are related to the duodenal irrigation, which is fixed, and the last travels along the cecum in order to nourish it, or to participate in its nourishment. The cecum looks like a dilated bag, or cecal bag, having two constrictions, one delimiting the entrance and one marking the exit. The entrance connects to the ileum and the exit to the colon. The spatial positioning of the small intestine of the lesser anteater, in relation to the mesentery and the mesocolon, allows the CrMA to run parallel to the CaMA and the ventral branches along the path of the CrMA to establish anastomoses between the two arterial beds, especially in the area of the ileocecal transition.

The cecum in the specimens of anteater studied was found to be irrigated by the CrMA. In most cases, the artery expanded to the colon region, corresponding to the region known as the right colic flexure. In reality, the colic flexures in the lesser anteater are not as clear as in other vertebrates (GETTY 1982, Evans 1993, Clauss et al. 2005, Diz et al. 2006, Pérez et al. 2008).

Some architectural analyses of the intestinal arteries of agoutis (CARvalHo et al. 1999) and nutrias (Culau et al. 2008) describe the CaMA reaching the left colic flexure. This condition differs from that found in the lesser anteater, in which the left colic flexure is irrigated by the CrMA. It can be inferred that the origin of the CrMA is compatible to that of more recent vertebrates. That is, it originates from the dorsal wall of the aorta in the retroperitoneum. The same does not apply to the path of the vessel, due to its spatial distribution in the peritoneum, as demonstrated by Grassé (1965) in other lower vertebrates.

In conclusion, the CrMA is an odd $(85.72 \%)$ or even (14.28\%) branch of the abdominal aorta and is ventral to the celiac trunk. The jejunal and ileal arteries run through the mesentery towards the intestine as dorsal primary collateral branches of the CrMA. The last ileal arteries contribute as secondary and tertiary, generally straight, branches to the vascularization of the cecal bag and the colon. The juxtaintestinal arched arteries run parallel to the duodenal, jejunal and ileal arches, and send out straight terminal branches that disseminate through the dorsal and ventral surfaces of the mesenteric border of the intestinal loops, penetrating their interior as microvessels. The mesentery of T. tetradactyla is different from that of other vertebrates recently described in the literature. This animal exhibits a basic vascular pattern relative to the ontogeny of vertebrates.

\section{ACKNOWLEDGEMENTS}

The authors thank Wladimir M. Domingues, who, through the Project of Capture of Roadkill Animals for Biology Studies and Conservation, has transferred part of this sample, thus avoiding the sacrifice of lives.

\section{LITERATURE CITED}

Barnwal, A.K.; D.N. Sharma \& L.D. Dhingra. 1982. Anatomical and roentgenohraphic studies on the cranial mesenteric artery of buffalo. Haryana Veterinary 21 (1): 1-5.

Bruni, A.C. \& V. Zimmerl. 1947. Anatomia degli animal domestic. Italy, Appiano Gentile, 763p.

Carvalho, M.A.M.; M.A. Miglino; L.J.A. Didio \& A.P.F. Melo. 1999. Artérias mesentéricas cranial e caudal em cutias (Dasyprocta aguti). Veterinária Notícias 5 (2): 17-24.

Clauss, M.; J. Hummel; F. Vercammen \& W.J. Streich. 2005. Observations on the macroscopic digestive anatomy of the Himalayan Tahr (Hemitragus jemlahicus). Anatomia, Histologia, Embryologia 34: 276-278. doi:10.1111/j.14390264.2005.00611.x.

Culau, P.V.O.; R.C. Azambuja \& R. Campos. 2008. Ramos colaterais viscerais da artéria aorta abdominal em Myocastor coypus (nutria). Acta Scientiae Veterinarie 36 (3): 241-247.

Didio, L.J.A.; A. Harb-Gama; J.R. Gama \& A.A. Laudanna. 1998. Sistema digestório, p. 463-582. In: L.J.A. Didio (Ed.). Tratado de anatomia aplicada. São Paulo, Pólus Editorial, 287p.

Diz, M.J.O.; B. Quse \& E.M. BRown. 2006. Registro de medidas y pesos del tubo digestivo de un ejemplar de Chaetophractus villosus. Edentata 7 (5): 23-25. doi: 10.1896/1413-4411. 7.1.23.

Evans, H.E. 1993. The heart and the arteries, p. 586-681. In: H.E. Evans (Ed.). Miller's anatomy of the dog. W.B. Philadelphia, Saunders Company, 1113p.

GARDNER, A.L. 2007. Cohort placentalia owen, 1837. Magnorder Xenarthra Cope, 1889, p. 127-177. In: A.L. GARDNER (Ed.). Mammals of South America, Marsupials, Xenarthrans, Shrews, and Bats. Chicago, University of Chicago Press, $669 \mathrm{p}$.

Getтy, R. 1982. Anatomia dos animais domésticos. Rio de Janeiro, Guanabara Koogan, 1134p.

Guadin, T.J. \& H.G. McDonald. 2008. Morphology based investigation of the phylogenetic relationship among exant 
and fossil Xenarthrans, p. 24-36. In: S. VizCAíno \& J.L. LouhHrY (Eds). The biology of the Xenarthra. Gainesville, University of Florida Press, 370p.

Grassé, P.P. 1965. Traité de Zoologie, Anatomie Systématique, Biologie Vertébres. Tome XII. Genéralites Embriologie Topographique, Anatomie Comparé. Paris, Masson et Cie Éditeurs, 1129p.

Hildebrand, M. \& G. Goslow. 2006. Celomas mesentéricos, p. 195-199. In: M. Hildebrand \& G. Goslow (Eds). Análise da estrutura dos vertebrados. São Paulo, Atheneu, 637p.

JunQUeIRA, L.C.U. \& D. ZAGO. 1977. Fundamentos da embriologia humana. Rio de Janeiro, Guanabara Koogan, 275p.

LAT ShaW, W.K. 1987. Veterinary developmental anatomy: a clinically oriented approach. Missouri, Mosby Company, 283p.

Lima, V.M.; A.L.S. Rezende; J.R. Ferreira \& K.F. Pereira. 2010. Distribuition of mesenteric cranial artery in the small intestine of Procyon cancrivorus (Cuvier, 1798) (Mammalian, Procyonidae). Acta Scientiarum Biological Sciences 32: 175-179. doi: 10.4025/actascibiolsci.v32i2.5839.

LlorCa, F.O. 1952. Intestino médio, p. 459-528. In: F.O. LlorCA (Ed.). Anatomia humana. Barcelona, Editorial Científico Médica, Tomo terceiro, 782p.

Machado, G.V.; P.R. Gonçalves; A. Parizzi \& J.R. SouZa. 2006. Padrão de divisão e distribuição das artérias mesentéricas no ratão-do-banhado (Myocastor coypus-Rodentia: Mammalia). Biotemas 1: 59-63.

Machado, M.R.F.; M.A. Miglino; V.P. Cabral \& N. Araújo. 2000. Origem das artérias celíaca e mesentérica cranial em bubalinos (Bubalus bubalis, L. 1758). Brazilian Journal of Veterinary Research and Animal Science 37: 99-104. doi: 10.1590/S1413-95962000000200002.

Moore, K.L. \& A.F. Dalley. 2007. Anatomia orientada para a clínica. Rio de Janeiro, Guanabara Koogan, 1101p.

Moore, K.L. \& T.V.N. Persaud. 2008. O sistema digestório, p. 214-244. In: K.L. Moore \& T.V.N. Persaud (Eds). Embriologia clínica. Rio de Janeiro, Elsevier, 536p.

Nickel, R. \& A. SChummer. 1977. The alimentary canal, general and comparative, p. 99-203. In: R. NiCKEL \& A. SCHUMmER (Eds). Anatomy of the domestic mammals. Hamburg, Verlog PauL Parey, 518p.

Noden, D.M. \& A. Lahunta. 1985. The embryology of domestic animals. Developmental mechanisms and malformations. Baltimore, Williams and Wilkins, 367p.
Nomina Anatomica Veterinaria. 2005. International Committee on Veterinary Gross Anatomical Nomenclature (I.C.V.G.A.N.). $5^{\text {th }}$ ed. Available on line at: http://www.wava-amav.org/ Dowloads/nav_2005.pdf [Accessed: 20/IX/2010].

Peduti Neto, J. \& I.L.S. Prada. 1970. Origem das artérias celíaca e mesentérica cranial, por tronco comum, em fetos de bovinos azebuados. Revista da Faculdade de Medicina Veterinária e Zootecnia da Universidade de São Paulo 8: 399402.

Pereira, J.G.L.; N. Ferreira \& A.A. D’Errico. 1978. A origem das artérias celíaca e mesentérica cranial, por tronco comum, em carneiros da raça Corriedale. Revista da Faculdade de Medicina Veterinária e Zootecnia da Universidade de São Paulo 15 (1): 19-22.

Pérez, W.; M. Clauss \& R. Ungerfeld. 2008. Observations on the macroscopic anatomy of the intestinal tract and its mesenteric folds in the pampas deer (Ozotoceros bezoarticus, Linnaeus 1758). Anatomia, Histologia, Embryologia 37: 317-321.

Pinto, M.R.A.; A.A.C. M. Ribeiro.\& W.M. Souza. 1998. Os arranjos configurados pelas artérias mesentéricas cranial e caudal no pato doméstico (Cairina moshata). Brazilian Journal of Veterinary Research and Animal Science 35 (3): 107-109.

RAVEN, H.C. 1950. The anatomy of the gorila. New York, Columbia University Press, 259p.

Rodrigues, R.F.; M.A. Miglino \& A.P.F. Melo. 2003. Vascularização arterial do trato gastrointestinal da Trachemys script elegans, Weid, 1838. Brazilian Journal of Veterinary Research and Animal Science 40 (1): 63-68.

SChwARZe, E. \& L. Schröder. 1970. El sistema visceral, p.11-118. In: E. SChwARZE \& L. SChröder (Eds). Compendio de anatomia veterinaria. Acribia, Zaragoza, Tomo II, 313p.

Souza, A.L.R.; L.C. Rezende; A.R. Mortoza \& J.R. Ferreira. 2010. Modelo de suprimento sanguíneo do intestino grosso do tamanduá bandeira (Myrmecophaga tridactyla). Ciência Rural 40 (3): 541-547.

Stevens, C.E. \& I.E. Hume. 1995. Comparative physiology of the vertebrate digestive system. Cambridge, Cambridge University Press, 400p.

Testut, L. \& A. Latarjet. 1960. Tratado de anatomia humana. Buenos Aires, Salvat Editores, Tomo IV, 1168p.

ZappaLÁ, A.A. 1963. Base anatômica da ressecção segmentar do baço. Anais da Faculdade de Medicina da Universidade de Recife 23: 7-3.

Submitted: 29.VII.2010; Accepted: 22.II.2011.

Editorial responsibility: Carolina Arruda Freire 